\title{
O TORNAR-SE ESCRITORA EM LÉSBIA (1890), DE MARIA BENEDITA CÂMARA BORMANN (DÉLIA)
}

\section{BECOMING A WRITER IN LÉSBIA (1890), BY MARIA BENEDITA CÂMARA BORMANN (DÉLIA)}

\author{
Pamela Raiol Rodrigues ${ }^{1}$ \\ [https://orcid.org/0000-0001-5395-2257] \\ Juliana Maia de Queiroz ${ }^{2}$ \\ [https://orcid.org/0000-0002-8297-3118] \\ DOI: $10.30612 /$ raido.v14i35.12123
}

\begin{abstract}
RESUMO: No romance Lésbia (1890), de Maria Benedita Câmara Bormann (Délia), a protagonista Arabela se torna uma afamada escritora no Oitocentos brasileiro. A fim de compreender como esta personagem feminina ascende socialmente em um período de privaçóes, fizemos uma pesquisa bibliográfica sobre a vida da mulher de elite no Brasil oitocentista (VERONA, 2013), delineando a relaçâo entre as mulheres e a literatura (HAHNER, 2018) e o panorama do mercado editorial do século XIX (DUARTE, 2017; HALLEWELL, 2017). O presente artigo tem como objetivo traçar um breve histórico acerca da vida feminina no Brasil Império, com o intuito de entender como se estabeleceu o vínculo entre as mulheres e a escrita literária em nosso nascente mercado livreiro. Para tanto, analisamos o enredo do romance, salientando as dificuldades enfrentadas na carreira de escritora da protagonista, causadas, sobretudo, por sua condiçâo enquanto mulher em um campo majoritariamente patriarcal. Por fim, observamos que a narrativa mescla História e ficçāo em descriçôes significativas da vida literária sob a perspectiva da mulher escritora no Oitocentos. Além disso, neste trabalho, intentamos valorizar a literatura feita por mulheres no século XIX e, assim, contribuir para o náo apagamento de Bormann (Délia), uma das primeiras escritoras brasileiras.
\end{abstract}

Palavras-chave: Mercado editorial; Mulher e Literatura; Lésbia; Maria Benedita Câmara Bormann; Século XIX.

ABSTRACT: In the novel Lésbia (1890), by Maria Benedita Câmara Bormann (Délia), the protagonist Arabela becomes a famous writer in Brazilian nineteenth century. In order to understand how this female character ascends socially in a period of deprivation, we did a bibliographical research on the life of elite woman in Brazilian eighteenth century (VERONA, 2013), outlining the relationship between women and literature (HAHNER, 2018) and the panorama of publishing market in the nineteenth century (DUARTE, 2017; HALLEWELL, 2017). The present article aims to trace a brief history of female's

1 É professora de Literatura e Língua Portuguesa na Secretaria de Educaçâo do Pará (SEDUC-PA) e mestranda no Programa de Pós-graduaçáo em Letras - Estudos Literários (UFPA).

2 É professora de Literatura Portuguesa na Universidade Federal do Pará (UFPA) e professora do Programa de Pós-Graduaçấo em Letras da UFPA. 
life during the Brazililian Imperial age, in order to understand how the bond between women and literary writing was established in our nascent book market. For this, we analyze the plot of the novel, highlighting the difficulties faced in the protagonist's writing career, caused mainly by her condition as a woman in a largely patriarchal field. Finally, we notice that the narrative blends History and fiction into meaningful descriptions of literary life from the perspective of woman writer in the nineteenth century. Moreover, in this work, we intend to value literature made by women in the nineteenth century and thus contribute to the non-erasure of Bormann (Délia), one of the first Brazilian female writers.

Keywords: Publishing market; Woman and Literature; Lésbia; Maria Benedita Câmara Bormann; Nineteenth Century.

\section{CONSIDERAÇÕES INICIAIS}

No século XIX, muitas mulheres escreveram no Brasil, entretanto, esse legado é, por vezes, apagado dos compêndios e histórias da literatura. Investigando a motivaçâo desse apagamento, notamos que as letras eram um campo no qual os homens faziam suas regras e poucas foram as chances que as mulheres puderam aproveitar. Isso se deu, em parte, pela pouca educaçâo a que as mulheres tinham acesso, pois, se até mesmo na elite era comum que elas fossem analfabetas, nas classes mais baixas, essa era a realidade da maioria. Após 1822, com a Independência do Brasil e o avançar do progresso socioeconômico, a educaçăo passou a ser vista pelos dirigentes como chave principal para a aparência que o Império Brasileiro intentava passar ao mundo. Assim, as mulheres começaram a ocupar espaços nâo antes destinados a elas, como os bancos escolares, e essa instruçáo foi um passo de suma importância para o projeto de emancipaçăo feminina, o qual, com o tempo, lutou por pautas como a liberdade de exercer profissōes, o divórcio e o voto.

Outro fator da maior relevância para as mudanças dos papéis femininos no Oitocentos foi o surgimento de inúmeros periódicos destinados às leitoras, que circularam durante o desenvolvimento do mercado editorial finissecular. As primeiras escritoras brasileiras escreveram nesses jornais e muitas delas lutavam por bandeiras que antecipavam a luta feminista no Brasil. Entre elas, figura o nome da escritora gaúcha Maria Benedita Câmara Bormann, conhecida como Délia, que escreveu em diversas folhas na capital do Império durante sua breve carreira no fim do século XIX.

O romance Lésbia (1890), de Délia, traz ao centro da cena uma moça de família rica chamada Arabela. Após o fim de seu casamento, atitude já à frente do seu tempo, ela se envolve com outro homem e, quando descobre estar sendo enganada, vive um desalinho pessoal que a leva a se recolher primeiramente em seus estudos e, depois, engaja-se no projeto de se tornar uma escritora de sucesso. Almejando alcançar a fama, passa por inúmeras situaçóes degradantes apenas por ser mulher em um mundo de figuras masculinas detentoras de poder. Essa vivência como escritora é o alvo de nossa análise neste artigo, com o objetivo de demonstrar como a obra fictícia de Bormann desenvolveu outros modos de ser mulher além do contexto doméstico, como máe e esposa.

Ser escritora, principalmente no Oitocentos, era uma atitude política e tanto autora quanto personagem lutaram para conseguir o seu lugar no năo esquecimento. Sobre isso, infelizmente, o que observamos hoje nas histórias literárias é uma ausência quase 
total dos nomes das primeiras escritoras brasileiras, estando Délia entre os nomes apagados. Por isso, também nos propomos a rememorar o trabalho literário dessa mulher que, por seu talento e singularidade, náo deve ser deixado à margem. Nosso trajeto neste artigo se inicia com "Os papéis femininos no século XIX", em que tratamos dos modelos previstos para as mulheres oitocentistas, passamos por "A mulher nas letras", em que comentamos as relaçôes das mulheres com a escrita no final do Oitocentos, relembramos Délia com a seçăo sobre a autora e finalizamos com o tópico analítico sobre "O tornar-se escritora em Lésbia", em que selecionamos trechos do romance para descrever como se deu a trajetória da mulher como escritora na narrativa, seguido de nossas consideraçôes finais.

Vale destacar que, em nossa pesquisa, descrevemos e analisamos a construçâo da personagem feminina presente na obra de uma escritora brasileira de classe alta - cujas personagens também pertencem à mesma classe -, portanto, as mulheres de quem falamos neste espaço, em geral, sâo as mulheres brancas, de elite, que conseguiram chegar ao campo das letras mais facilmente, se comparadas com as mulheres negras escravizadas ou trabalhadoras livres daquele momento histórico. Portanto, ao tratarmos das mulheres brasileiras oitocentistas, leia-se: as mulheres socialmente privilegiadas.

\section{OS PAPÉIS FEMININOS NO SÉCULO XIX: CONTEXTO HISTÓRICO}

Durante o século XIX, o Rio de Janeiro passou por mudanças políticas e econômicas que modificaram os seus modos de vida como um todo. Essas transformaçóes foram irradiaçôes das que ocorriam na Europa, cujos movimentos socioeconômicos chegavam até as naçôes que tinham ligaçōes diretas ou indiretas com os países do velho continente. Assim, com as mudanças causadas pela Revoluçăo Industrial, como a ascensâo da burguesia, as naçóes recém independentes, como o Brasil, recebiam os novos modelos de vida europeus através das influências vindas de navio para a ex-colônia. Esses conceitos importados muito influenciaram a elite de letrados que vivia no Brasil - inclusive os dirigentes -, o que determinou o contexto cultural-literário da época. (SANTOS, 2010).

Além de observar que as mudanças nos padrôes europeus influenciaram o modo de pensar dos dirigentes no Brasil, é necessário pontuar que um dos principais fatores para a mudança significativa nas terras da ex-colônia foi a transferência da família real portuguesa para o Rio de Janeiro em 1808. Essa mudança trouxe consigo elementos essenciais para a busca do progresso através da instruçăo e dos ensinamentos morais, os quais deveriam ser passados para os portugueses e brasileiros habitantes da capital do Império. Dessa forma, na intençăo de se parecer o máximo possível com o europeu, o modus vivendi na ex-colônia foi alterado, ainda que existissem diferenças cruciais, como a questăo da economia baseada na escravidăo, pontuada por Roberto Schwarz (2000).

De acordo com Elisa Verona (2013, p. 19), "literatos, médicos, juristas, educadores e outros agentes sociais também enfatizaram a necessidade de intervençâo na sociedade como forma de atingir o progresso, e o fizeram de diversas formas". Assim, a partir da transferência da família real, todos os cidadăos que viviam no Rio de Janeiro se 
empenhavam na ideia de formar uma naçăo independente, a qual respirasse inovaçóes e, por isso, a vida de todos foi modificada.

Em relaçăo às mulheres, grande mudança ocorreu entre a primeira e a segunda metade do século XIX, tendo em vista que o movimento de modificaçóes na sociedade carioca se estabeleceu, principalmente, no período do Segundo Reinado (1840 - 1889). Antes, as mulheres de elite seguiam apenas os padróes de comportamento reclusos. Entretanto, este cenário começou a se modificar com a chegada das modernidades à capital. Tais mudanças estavam relacionadas à urbanizaçâo dos espaços, a qual causou uma alteraçáo nos comportamentos femininos, mas sem perder de vista que o decoro era sempre prezado, porque a "verdadeira rainha do lar deveria repudiar o que náo fosse recato, discriçăo e virtude" (VERONA, 2013, p. 34). Dessa maneira, a vida da mulher brasileira foi se modificando, pois a ela cabia papel formidável na nova ordem social da capital do Império. Vejamos qual papel é esse a seguir.

Acerca das mulheres abastadas, a pesquisadora brasileira Maria Ângela D'Incao observa que a possibilidade do ócio "incentivou a absorçâo das novelas românticas e sentimentais consumidas entre um bordado e outro, receitas de doces e confidências entre amigas" (D'INCAO, 2018, p. 229). Isso marca o grupo de mulheres sobre o qual estamos descrevendo os comportamentos neste trabalho: a mulher de elite, que tinha tempo para leituras. Ademais, a autora nota que "cada vez mais é reforçada a ideia de que ser mulher é ser quase integralmente mâe dedicada e atenciosa, um ideal que só pode ser plenamente atingido dentro da esfera da família 'burguesa e higienizada"' (D'INCAO, 2018, p. 229). Portanto, era dever da mulher de elite desta época dedicar-se sempre à família em primeiro lugar e, caso se interessasse por outros afazeres, infringiria uma regra de comportamento fundamental na construçăo dos grupos familiares em ascensâo naquele período: as famílias burguesas.

Sobre as já citadas mudanças ocorridas na sociedade carioca da metade do século XIX, é importante observar que, com a chegada de modernidades como os trens e a eletricidade, para citar algumas, o desenvolvimento das cidades, em geral, fez com que o espaço no interior das residências fosse reconfigurado. E, como pontua D'Incao (2018, p. 228), isso "deixou ainda mais claros os limites do convívio e as distâncias sociais entre a nova classe e o povo, permitindo um processo de privatizaçăo da família marcado pela valorizaçăo da intimidade". De acordo com a pesquisadora, as casas mais ricas passaram por um processo de abertura a um círculo restrito de familiares e amigos. Além disso, aconteciam saraus, jantares e festas de tempos em tempos nas salas de visita e nos salôes - espaços intermediários entre a casa e a rua. (D'INCAO, 2018).

Nesse ínterim, a mulher de elite passou a marcar presença em cafés, bailes, teatros e certos acontecimentos da vida social. Nota-se, a partir de D'Incao (2018, p. 228), que

nas casas, domínios privados e públicos estavam presentes. Nos públicos, como as salas de jantar e os salóes, lugar das máscaras sociais, impunham-se regras para bem receber e bem representar diante das visitas. As salas abriam-se frequentemente para reuniôes mais fechadas ou saraus, em que se liam trechos de poesias e romances em voz alta, ou uma voz acompanhava os sons do piano ou harpa.

Para esse convívio social que se abria aos parentes e amigos da família, a mulher abastada aprendia como se portar por meio de mecanismos tais quais as cartilhas de boas maneiras, disponíveis em periódicos, além da literatura lida pela mulher brasileira, 
conhecida como exímia leitora de romances no Oitocentos. Essas ferramentas visavam a instruçăo que, como veremos, era o objetivo geral da naçăo, de modo a tornar o país mais desenvolvido intelectual e socioeconomicamente.

Salete dos Santos (2010) pondera que, apesar dessas mudanças ocorridas no comportamento da mulher brasileira, pode-se afirmar que o processo de invisibilidade social sofrido pelas mulheres encontra, ainda no século XIX, inúmeros locais que eram projetados por homens para serem usados apenas por eles mesmos: "É do homem o âmbito público, o direito de ir e vir e de exercer poder sobre a família. A ele estâo sujeitas mulheres, esposas e filhas, as quais lhe devem obediência irrestrita" (SANTOS, 2010, p. 24). Portanto, os hábitos das mulheres modicaram-se aos poucos, seguindo os passos do progresso, todavia, é necessário destacar que a sociedade continuou em seus moldes patriarcais, os quais limitavam as mulheres.

Voltando à questăo da instruçăo, Elisa Verona (2013, p. 9-10) pontua que, "na ótica da intelectualidade oitocentista, a instruçâo constituía um aspecto indispensável para o aprimoramento social, peça fundamental para o desenvolvimento de uma naçāo civilizada". Essa instruçâo se tornou, notadamente, o motor de muitas modificaçóes na sociedade carioca de entăo. Em seu trabalho, Verona reuniu diversos depoimentos e documentos provenientes dos homens de política, os quais ressaltam o papel dessa instruçăo para a sociedade da época, que era totalmente relacionado com a difusăo de preceitos morais. Conforme podemos comprovar no trecho do ilustre político brasileiro Rui Barbosa:

É, com efeito, profunda convicçáo nossa que a influência melhoradora, prosperadora, civilizadora da instruçâo popular depende absolutamente da sua associaçăo contínua, íntima, indissoluvel (sic) à substância do cultivo moral. [...] Instruir náo é simplesmente acumular conhecimentos, mas cultivar as faculdades por onde os adquirimos, e utilizamos a bem do nosso destino. Se năo as educamos simultaneamente na direçáo da esfera intelectual e na direçăo da esfera moral, têlas-emos condenado a um desenvolvimento incompleto. (BARBOSA, 1946, pp. 365366 , grifo do autor).

Assim, nota-se que, para os homens de poder, os quais pensavam e legislavam acerca de como a educaçáo deveria se dar na época, a moral era de extrema necessidade para o sistema educacional. Sem ela, os conhecimentos construídos seriam incompletos, o que fazia com que, aos ensinamentos de caráter éticos e morais, fosse dada maior valoraçăo.

Neste período, alguns mecanismos cresceram em importância nesta missăo de educar e pregar a boa moral. Nâo era mais apenas a igreja que, através do púlpito e do confessionário, ditava regras de conduta. Os periódicos, os romances, novelas e manuais de civilidade cumpriam a finalidade de educar as leitoras. "Por entre esses ditos e escritos forjavam-se modelos que interessavam à manutençăo da, tăo cara, ordem social. E, nesse processo, um desenho de mulher ia sendo delineado, sobretudo por măos masculinas" (VERONA, 2013, p. 35).

Sobre tais máos masculinas, podemos citar que, no Brasil, de acordo com Regina Zilberman e Marisa Lajolo (2019), autores como José de Alencar, Joaquim Manuel de Macedo e Machado de Assis merecem destaque na manutençáo dos estereótipos de ideal feminino no século XIX. Suas narrativas corroboram os valores da sociedade patriarcal oitocentista e, conforme Santos (2010), apresentam protagonistas finas, com educaçáo esmerada, as quais reforçavam o papel social da mulher como esposa e măe dentro do lar. 
Em diálogo com o projeto literário dos romancistas citados acima, Santos (2010, p. 30) defende que "nâo era interesse da sociedade que determinadas ideias influenciassem o comportamento feminino, como buscar aperfeiçoamento intelectual com vistas ao exercício de alguma profissáo fora de casa". A autora destaca ainda que, mesmo que as personagens femininas sejam capazes de discutir em "pé de igualdade" com os homens em alguns momentos, "os autores nâo promovem denúncia das condiçóes de vivência feminina, ao contrário, matizam essa situaçăo com as cores da idealizaçáo, autenticando o estabelecido" (SANTOS, 2010, p. 30). Portanto, a literatura produzida pelos autores era fator de ajuda em educar a leitora, pois o romance tinha o intuito de ensinar como se levar a vida da melhor forma possível, além de o que se deveria fazer e o que nâo se deveria. Era, pois, forte instrumento educativo.

Santos (2010) ainda observa que o "malefício", advindo da convivência feminina com o universo ficcional, encontrava-se na possibilidade de a jovem iniciar um processo de conscientizaçáo e passar a questionar os comportamentos sociais, reavendo seu lugar na sociedade. E qual era o papel da mulher no desenvolvimento da naçăo? Como essa mulher foi afetada por melhorias no campo da educaçáo? Falemos um pouco da educaçâo formal feminina.

Guacira Louro (2018) observa que um discurso ganhava a hegemonia social naquele período: "a afirmaçấo de que as 'mulheres deveriam ser mais educadas do que instruídas', ou seja, para elas, a ênfase deveria recair sobre a formaçāo moral, sobre a constituiçâo do caráter, sendo suficientes, provavelmente, doses pequenas ou doses menores de instruçăo" (LOURO, 2018, p. 446, grifo da autora). Caso elas aprendessem além do "necessário", poderiam até sofrer consequências negativas, pois, como pontuou Santos (2010, p. 29), "ser detentora de qualquer outro saber seria colocar em risco a segurança do lar".

Além do bom casamento, um único motivo a mais para essa mulher se educar seria o fato de que a mâe é a primeira educadora dos filhos. Assim, jamais para si próprias, mas sim para bem representar os maridos e, depois, para educar os filhos, a mulher brasileira de elite no Oitocentos foi instruída. Com o passar do tempo e com alguma instruçăo, grupos de mulheres vieram a escrever as suas próprias reivindicaçóes. Apesar do fato de que sua educaçáo nunca visou seu próprio crescimento, esse desenvolvimento chegou e se mostrou de diversas formas, inclusive através da literatura e da arte em geral.

Foi através da educaçăo - ainda que esta, naquele momento histórico, em nada apontasse para carreiras profissionais - que algumas mulheres superaram as barreiras erguidas em torno de suas mentes e corpos pela sociedade patriarcal e conquistaram seus lugares em algumas carreiras profissionais. Por fim, é relevante pontuar que, por meio da alfabetizaçấo, a mulher oitocentista conseguiu a instruçâo necessária para, depois, aventurar-se nas letras e publicaçôes, sobre o que trataremos agora.

\section{A MULHER NAS LETRAS}

Atualmente, sabe-se que muitas mulheres exerceram profissōes no Brasil no final do século XIX, ainda que, para a sociedade oitocentista em geral - principalmente para os homens defensores de uma cultura patriarcal -, a educaçăo da mulher só pudesse almejar o "necessário", o que, para eles, era a educaçâo dos filhos e a boa representaçăo do marido. Estes eram os modelos sociais ditados para a mulher brasileira de elite naquele momento: esposa recatada e boa măe. 
Maria Ângela D'Incao (2018) assinala que o fortalecimento desse ideal feminino se deu por meios médicos e educativos, bem como pela imprensa, a qual formulou uma série de propostas que visavam educar a mulher para a sua funçâo de guardiâ do lar e da família. "Considerada base moral da sociedade, a mulher de elite, a esposa e mâe da família burguesa deveria adotar regras castas no encontro sexual com o marido, vigiar a castidade das filhas, constituir uma descendência saudável e cuidar do comportamento da prole" (D'INCAO, 2018, p. 230). Em resumo, é evidente que a emergência da família burguesa, ao reforçar no imaginário a necessidade do amor familiar e do cuidado com o marido e com os filhos, redefine o papel feminino e, ao mesmo tempo, reserva, para a mulher, novas atividades no interior do espaço do lar. (D'INCAO, 2018). Assim, embora tenha sido tarefa hercúlea tentar exercer atividades fora de casa para a mulher de elite do Oitocentos na capital do Império, algumas mulheres exerceram profissóes, inclusive ligadas às letras.

Relacionado às mulheres que escreviam no século XIX, sabemos que este período foi fundamental na formaçăo de um público leitor no Brasil e os periódicos foram meios de comunicaçâo indispensáveis para a circulaçâo de obras literárias. Nas letras, mulheres - em geral de elite - também ocuparam alguns espaços, chegando a publicar em jornais e revistas. Sobre isso, destaca-se que, na década de 1870, houve um aumento significativo no número de publicaçōes de mulheres em periódicos e o que começou apenas com mâos masculinas, dirigindo-se ao público feminino, passou a ser também escrito pelas mulheres. De acordo com a pesquisadora June Hahner (2018), muitos desses jornais - mesmo os que publicavam artigos escritos por mulheres - dedicavam-se, porém, apenas a assuntos como moda ou literatura sentimental. Entretanto, uma parte corajosa já mostrava novas intençōes a partir da escrita:

Afinal, agora, as mulheres de classe alta seguiam as modas francesas com muito mais empenho do que no início do século, além de lerem mais romances. Entretanto, algumas editoras de jornais - uma minoria corajosa - advogavam pela emancipaçăo das mulheres, enfatizando a importância da educaçáo básica, tanto em benefício particular quanto para melhorar o mundo. (HAHNER, 2018, p. 60-61).

Logo, as mulheres passaram a escrever os seus próprios periódicos, cujas bandeiras eram hasteadas em prol da luta por educaçăo de qualidade para o público feminino, isto é, sua instruçâo, o que traria benefícios no campo das profissōes, desenvolvimento pessoal e social, entre outros ganhos. Ainda sobre esse assunto, Constância Lima Duarte em Imprensa feminina e feminista (2017) pesquisou os periódicos fundados por mulheres ou escritos para mulheres e ressalta que a literatura, a imprensa e a consciência feminista surgiram praticamente ao mesmo tempo no Brasil, já nas primeiras décadas do século XIX. Segundo ela, "quando as primeiras mulheres tiveram acesso ao letramento, imediatamente se apoderaram da leitura, que por sua vez as levou à escrita e à crítica" (DUARTE, 2017, p. 14). Assim, notamos que, em meio à resistência social, muitas mulheres foram alfabetizadas e se desenvolveram para além do que os seus pais e maridos desejavam. Ademais,

independente de serem poetisas, ficcionistas, jornalistas ou professoras, a leitura lhes deu consciência do estatuto de exceçáo que ocupavam no universo de mulheres analfabetas, da condiçáo subalterna a que o sexo estava submetido, e propiciou o surgimento de escritos reflexivos e engajados, tal a denúncia e o tom reivindicatório que muitos deles ainda hoje contêm. (DUARTE, 2017, p. 14). 
Reiteramos que a sociedade desta época criou uma fórmula do que era ser uma mulher "de família", um ideal de mulher que deveria ser seguido por todas que queriam estar dentro dos "bons costumes". "A receita para a mulher ideal envolvia uma mistura de imagens [...]. Mas todas elas convergiam para a pureza sexual - virgindade da moça, castidade da mulher. Para a mulher ser 'honesta' devia se casar; năo havia outra alternativa" (FONSECA, 2018, p. 528). Além disso, como observamos antes, até mesmo os romancistas fizeram a sua parte - valorosíssima - por este ideal. Ao criarem enredos e personagens que visavam instruir as leitoras moralmente, esses escritores desenhavam papéis femininos idealizados que já circulavam na sociedade oitocentista, como observamos ao citarmos Alencar, Macedo e Machado no tópico sobre os "papéis femininos". Em contrapartida, as mulheres, quando se apossaram da pena, buscaram reivindicar direitos que nunca tinham sido concedidos antes para seu grupo.

Tal qual registra a pesquisadora, organizadora da proveitosa obra Escritoras brasileiras do século XIX, Zahidé Muzart: “Uma das razōes para a criaçăo dos periódicos de mulheres no século XIX partiu da necessidade de conquista de direitos. Em primeiro lugar, o direito à educaçáo; em segundo, o direito à profissăo e, bem mais tarde, o direito ao voto" (MUZART, 2003, p. 226). Apesar de toda a luta feminina, quase nâo há mençâo aos seus nomes nos livros de historiografia literária. Uma escritora de destaque, durante o Oitocentos brasileiro, foi Maria Benedita Câmara Bormann, conhecida como Délia, cujo romance Lésbia aqui analisaremos. Tratemos, antes, de relembrar a escritora.

\section{RELEMBRANDO DÉLIA}

No Diccionario Bibliographico Brazileiro, escrito pelo baiano Augusto Victorino Alves Sacramento Blake e impresso pela Imprensa Nacional em 1900, no Rio de Janeiro, temos, no sexto volume, a seguinte entrada: D. Maria Benedicta Camara de Bormann. Blake registra: "Filha de Patricio Augusto da Camara Lima e dona Maria Luiza Bormann de Lima, nasceu em Porto-Alegre a 25 de novembro de 1853, foi casada com o doutor José Bernardino Bormann, seu tio [...], e falleceu na cidade do Rio de Janeiro a 23 de julho de 1895" (BLAKE, 1900, p. 226). Também sobre a biografia da autora, Norma Telles ${ }^{3}$ registra que ela tinha por volta de dez anos quando a família se mudou para o Rio de Janeiro em 1863 e se fixou no antigo centro histórico, área ainda respeitável, habitada por comerciantes e pequenos funcionários. O pai de Maria Benedita, Patrício Augusto, era funcionário público, conferente da Alfândega da Corte segundo os documentos.

Ela dedicou-se às letras, começando a escrever aos catorze anos. Entretanto, estes primeiros trabalhos de escrita foram descartados por ela por lhe parecer que nenhum mérito tinham. (BLAKE, 1900). Blake também destaca que Bormann colaborou com diversos periódicos, como O Sorriso (1800-1801); O Cruzeiro (1882); a Gazeta da Tarde (1883-1884), entre outros. Além de ter escrito em volume, isto é, em livro, os romances: Aurélia (1883); Uma vítima, Duas Irmās, Madalena (1884); Lésbia, A estátua de neve (1890); Celeste (1993) e Angelina (1894). Destaca-se que Aurélia, Uma vítima e Madalena foram publicados antes em folhetins nos periódicos.

3 Disponível em: http://www.normatelles.com.br/memorial_da_pesquisa.html Acesso em: 15 abr 2020. 
Deste verbete no dicionário bibliográfico de Sacramento Blake, podemos observar que, desde que começou suas publicaçōes em periódicos e em livros, Bormann manteve grande ritmo, o que, para aquele momento histórico do mercado editorial, implicava grande aceitaçăo dos leitores. Segundo o autor, seu último romance, Angelina, foi publicado em 1894, um ano antes de seu falecimento, o que indica que ela escreveu até bem próximo de sua prematura morte. De grande produtividade, a autora era elogiada em notas nos jornais nos quais publicava, e, por mais que tenha sido louvada em sua época, caiu no esquecimento por năo figurar nas historiografias, as quais trouxeram para o século atual poucos nomes que foram canonizados e quase nenhum nome de mulher.

Ainda em textos do final do século, temos o essencial registro sobre Délia no livro da intelectual oitocentista Ignez Sabino. No seu Mulheres Illustres do Brazil (1890), Sabino escreve a biografia de mulheres consideradas por ela como ilustres e cujas memórias năo deveriam ser apagadas pelo passar do tempo. Na parte que coube à Délia no seu "panthéon feminino", temos: "filha de Porto Alegre, e de paes illustres, esposa do distinctissimo engenheiro, desde pequena mostrara singular intelligencia, vivacidade e espirito" (SABINO, 1996, p. 192). A autora registra que Délia tinha uma beleza adorável e maneiras finíssimas de mulher de salăo. Além de ser amante das artes, instruída, cantava com magnífica voz de meio soprano, tocava piano, desenhava e conversava tudo elegantemente -, pois possuía a alma culta. (SABINO, 1996).

Poucas săo as figuras presentes no livro de Sabino, Délia é uma das onze mulheres cujos retratos sâo estampados no volume. Sáo preciosas as imagens da escritora que circulam atualmente. A raridade é tanta que existe até mesmo um sério equívoco envolvendo a escritora oitocentista Maria Firmina dos Reis, cuja face hoje năo tem registro oficial e, por algum tempo, utilizaram-se do rosto de Délia como sendo o de Firmina, o que pode ser lido como uma forma de apagar a imagem da escritora negra abolicionista, autora de Úrsula (1859). A figura abaixo é retirada do livro de Ignez Sabino e é a mesma que circulou como se fosse de Maria Firmina dos Reis.

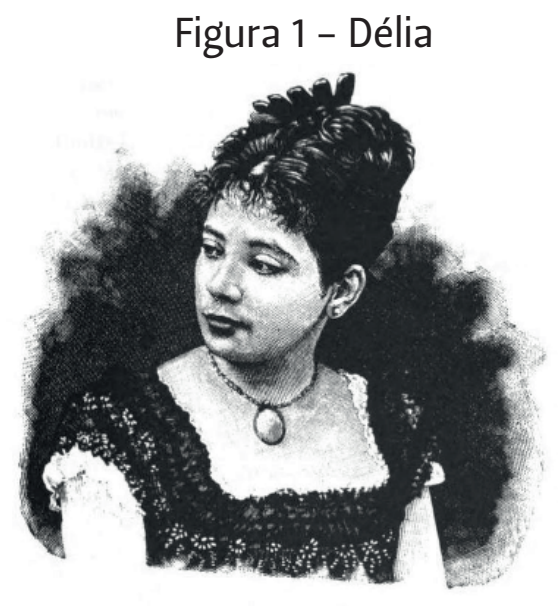

Fonte: Mulheres Illustres do Brazil, 1996.

Délia lançou-se no mundo das letras, sujeitando-se aos aplausos e às injustiças de um público que, às vezes, aceitava ou repudiava qualquer trabalho por capricho. Ela começou a escrever na Gazeta da tarde, fundada por Ferreira de Menezes. Depois, passou a escrever, desde a fundaçăo do periódico, em O Paiz, no qual entrou ao lado 
de Quintino Bocaiuva e de outros nomes sagrados na imprensa diária oitocentista. Foi neste último periódico que Bormann amadureceu seu talento como ilustrada contista. (SABINO, 1996). Com isso, ela principiou a conquistar um bonito nome que se tornou conhecido rapidamente.

Sabino registra que a autora de Lésbia era como um "Zola de saias", fazendo referência ao escritor francês naturalista Emilé Zola, o que Norma Telles destaca năo ser adequado, pois Délia "percorre as várias escolas literárias, retirando delas o que lhe apraz" (TELLES, 1998, p. 11). Sabino também aponta que a escritora deixou em Lésbia o seu melhor trabalho. Neste romance, a intelectual crê que se faz a autobiografia da autora, demonstrando a tendência oitocentista de pôr em traços de realidade tudo o que fosse escrito pelos literatos naquele período.

O registro de Sabino é de grande relevância na pesquisa biográfica de Délia, mas, apesar disto, a autora demonstra que náo compreende a essência da obra de Bormann quando diz que Celeste, seu último livro, ${ }^{4}$ seria "incompreensível e tresloucado, livro mau de psicologia" (SABINO, 1996, p. 197). Por fim, a intelectual finaliza a biografia afirmando que Délia tem direito de ser lembrada, com o que concordamos e buscamos participar do resgate da memória literária dessa escritora por meio do presente artigo.

Sobre o pseudônimo escolhido por Bormann, destaca-se que ela escolheu um nome de pena para si mesma que aponta para a Antiguidade clássica - esse mundo de homens eruditos e dos espaços vedados às mulheres. Assim, ao batizar a si mesma como Délia, a autora marca, segundo Telles (1998), uma ruptura com a divisâo cultural do conhecimento que se difundira na cultura através de uma linha divisória dos gêneros masculino e feminino. "Aos homens, todas as áreas do conhecimento e da produçâo cultural; às mulheres, um verniz de educaçăo para uma conversa de salâo, reproduçâo e cuidado com os filhos" (TELLES, 1998, p. 8). Telles (1998) também observa que essa escolha do nome indicava o posicionamento político de Bormann, pois, nas décadas que precederam a República, nomes romanos eram adotados para assinalar essa opçâo. Além disso, o nome

[...] esboça o traçado de uma genealogia própria, imaginária, uma genealogia feminina que tem início com a poeta Safo, passa pela personagem romana Délia e as denominadas Safos dos séculos subseqüentes (sic) chegando até George Sand, a Safo que dominou Paris em meados do século dezenove e de quem Maria Benedita Bormann diz, ter demonstrado "o que pode o gênio em peito feminino". (TELLES, 1998, pp. 8-9).

Portanto, podemos ressaltar que a escolha do nome de pena da escritora longe está de ter sido aleatória. Por meio de seus saberes, ela escolheu o pseudônimo ideal, que transparecia seu olhar social - era amante do progresso e da República e a favor do término da escravidâo -, bem como também funcionaria como uma genealogia dos nomes de escritoras que vieram antes dela, abrindo, de certa maneira, o caminho que ela poderia trilhar na arte de escrever. Ademais, é necessário pontuar que, conforme observou Telles (1998), o pseudônimo nâo funcionava, tal qual para muitas anteriormente, como forma de disfarce do seu gênero a fim de melhor caminhar no mundo

4 Alguns autores destoam sobre qual foi o último livro, em relaçăo à cronologia das publicaçōes. Sacramento Blake diz um e Sabino, outro. 
predominantemente masculino da literatura. Para Délia, o pseudônimo era um segundo batismo, um nascimento de uma nova vida a se acoplar na que já existe, o nascimento da escritora no espaço corporal e mental onde antes só havia a mulher. Passemos à leitura e análise do recorte do enredo do romance em que verificamos como se deu a transformaçáo da mulher em escritora em Lésbia.

\section{TORNAR-SE ESCRITORA EM LÉSBIA}

Escrito por Maria Benedita Câmara Bormann em 1884, Lésbia foi publicado em 1890 pela Tipografia de Evaristo Rodrigues da Costa. O romance narra a história de Arabela Gonzaga, a Bela, como era conhecida. Moça de família privilegiada, ela é casada com um homem que se mostra muito distinto do que aparentou no momento da conquista. Por causa dessa desilusăo, a protagonista manda o marido embora e volta a viver com os pais após uma discussăo. Ainda que essa atitude possa ser considerada uma ruptura do padrăo social feminino oitocentista, observa-se, na leitura crítica do romance, que a personagem náo tripudia sobre sua atitude, pelo contrário, ela se mostra frágil e triste por conta do acontecido. A família como um todo acaba reagindo com tristeza: "descrever a tristeza que se seguiu no lar de Bela é ocioso. Nos primeiros dias, só se viam aí semblantes anuviados, mudez e solidăo" (BORMANN, 1998, p. 50).

Nos flashbacks que o romance traz, descobrimos que a personagem tinha uma ótima relaçáo com os pais e que já possuía "espírito artístico" e uma personalidade impecável desde a adolescência, sendo muito inteligente. Com o espírito cheio de originalidades, é fácil compreender como ela desenvolveu a vontade de ser literata. Ademais, quando temos contato com as cenas da época do casamento, vemos uma mulher detentora de saberes que nâo eram tâo comuns às mulheres, devido à educaçâo feminina ter se dado em "marcha lenta" naquele momento, como observamos em nossa contextualizaçâo histórica no início deste artigo.

Uma das divergências que existiam entre ela e o marido era justamente o fato de ele sempre implicar com as leituras mantidas por ela, que eram exibidas em seus discursos cotidianos. Como notamos em uma cena à mesa, com os familiares e amigos de Bela, ela discorre sobre ser inata na criatura a admiraçâo pelo belo e ele pergunta, com ar grosseiro e bestial: "Em que romance leste esta frase?" (BORMANN, 1998, p. 45). Ela responde à pergunta e ele "teve ímpetos de estrangulá-la e riu convulso com o riso bilioso dos verdugos" (Idem). Quando se separam, ela se entrega ainda mais aos romances, já se mostrando com ares de escritora.

Algum tempo depois da separaçâo, encorajada pelos pais, Bela volta a frequentar a sociedade carioca, participando de festas e saraus. Em um determinado momento, ela conhece um político chamado Sérgio de Abreu, por quem se apaixona. Esse indivíduo, que julgava as mulheres e as tinha como conquistas, quando toma conhecimento de que Bela nâo se interessava facilmente pelos homens após a sua separaçâo do marido, enxerga nela uma conquista valorosa, a qual alcança. Utilizando-se de ousadia e violência, no momento em que ele deposita um beijo arriscado na escápula de Bela, "sentindo ele uma onda de sangue invadir-lhe o cérebro, e calculando que às vezes a ousadia e a violência obtêm no amor grandes resultados, resolveu utilizar-se dessa extremidade" (BORMANN, 1998, p. 59). O relacionamento dos dois dura um ano, sendo finalizado pela 
descoberta por parte da moça de que Sérgio era frequentador de bordéis e mantinha relaçôes com outras mulheres.

Após esse segundo término, Bela se sente incapaz de tudo, o que nos permite afirmar como sua trajetória de vida é de ascensão. Saindo de um conjunto de infortúnios, ela descobre um desejo interno e pessoal que a realiza como pessoa e artista: o sonho de alcançar a glória como escritora. Entretanto, isso năo se dá rapidamente nem sem sérios percalços que dificultam sua caminhada no mundo das letras. Sua motivaçâo é fortalecida quando ela encontra o livro Máximas de Epicteto e, após a sua leitura, sente-se determinada a perseguir seus objetivos: "eu saberei vencer o que tanto me oprime, porque sei querer e hei de triunfar!" (BORMANN, 1998, p. 74). E, ainda mais importante, ela se pergunta: "E por que năo escreverei tudo que me vêm à mente?... Acaso sofreram mais do que eu os que escrevem?... talvez, nem tanto!" (BORMANN, 1998, p. 75).

Decidida a escrever, ela se pergunta se a glória e a apreciaçâo pública poderiam ser capazes de compensar os seus sentimentos tăo cheios de tristezas. Respondendo que năo, questiona, entăo, para que serviriam. Assim, resolve que escreverá para si mesma, pois, dessa forma, evitaria maus êxitos que poderiam irritá-la e aumentar seus pesares. Dali em diante, o toucador foi transformado em gabinete de estudo, marca da transformaçăo que ocorre com a protagonista até esta altura da narrativa, contida entre os capítulos I e VII. Sobre isso, estamos de acordo com o apontado por Norma Telles (1998) acerca desse recorte da ficçầo, visto que, para ela, os primeiros sete capítulos podem ser considerados como a gênese e formaçăo da escritora, pois é quando nos săo apresentadas as mazelas sofridas pela protagonista, as quais foram influências diretas em seu desabrochar artístico.

A partir do capítulo VIII, Bela segue aplicada aos estudos e, investigando o passado e suas próprias feriadas, escreve seu primeiro romance, denominado História de uma paixâo. Ao compartilhar com os pais a sua obra, acredita que os elogios tecidos por eles săo exagerados, visto que os pais tendem a "duplicar o mérito filial e a associar-se a esperanças, muitas vezes infundadas" (BORMANN, 1998, p. 79). Dessa maneira, a escritora resolve pedir a outrem que faça a leitura e o escolhido é o amigo e médico da família, o doutor Luiz Augusto. A presença do médico como figura importante dentro do contexto familiar pode ser lida como marca de naturalismo presente no romance, simbolizando a medicina e os assuntos da área que permeiam a narrativa, como a questăo das nevroses femininas, citadas mais de uma vez. O fato de Bela pedir a ele por uma segunda leitura pode ser interpretado como prova de sua racionalidade, pois os pais năo configuravam crítica suficiente para ela pelo motivo já mencionado, fazendo com que ela procure por uma opiniáo mais isenta. $O$ médico aceita a tarefa, mas avisa que é fraco em literatura por só ler escritos médicos há tempos. Citando Arsène Houssaye, ele diz que, "pelo todo da autora, desde já posso afirmar que a obra é um primor!" (BORMANN, 1998, p. 80).

Enquanto aguarda a opiniăo do médico, Bela demonstra sentir ansiedade sobre a vida de escritora. Ela afirma que existe um terror de quem "expōe o filho d'alma aos azares do mundo" (BORMANN, 1998, p. 81), isto é, seus trabalhos literários, tidos como suas crias. Finalmente, o leitor retorna com suas impressōes e, apesar de reafirmar que náo é um homem de letras, descreve o seu sentimento: "o seu escrito incomoda e magoa como os gritos de uma dor intolerável! Nâo sou homem de letras, năo sei analisar o seu trabalho do 
ponto de vista literário, mas como observador das coisas humanas, acho-lhe palpitante veracidade. [...]Enfim, escrevem os outros com a cabeça, você com o coraçăo" (Idem).

A escritora reage com felicidade ao comentário do amigo, pois, para ela, "enternecer o leitor é prendê-lo, constituindo esse resultado um pequeno triunfo" (BORMANN, 1998, p. 82). Esse trecho é significativo para nossa leitura, pois recorda a teoria da estética da recepçăo, ao descrever como o texto chega ao leitor e como se deu a interaçấo entre leitor e obra, constituindo, para cada horizonte de leitura, uma interpretaçấo diferente, ainda que partam da leitura de uma mesma obra. A recepçāo do médico é descrita: "O seu romance, Bela, é um grito de maldiçōes e tem muitas cenas semelhantes a outras em que fui triste protagonista; por isso me incomodou tanto!... E tudo passou!... Minha juventude nâo existe, morreu, se bem que eu ainda viva!" (BORMANN, 1998, p. 83). Por fim, neste momento, o médico finaliza suas impressóes incentivando a escritora a ir avante na sua produçấo escrita com as palavras de Byron: "Away, away!"s (BORMANN, 1998, p. 84).

Essa opiniâo amiga encoraja a escritora a enviar o romance ao redator chefe de uma folha conservadora, o qual aceita a obra e a publica no rodapé do jornal. Essa primeira aceitaçăo de Bela na imprensa é um ponto relevante de análise, pois, nesse momento, a narradora observa que esse redator duvidava que a autoria daquele trabalho fosse feminina, como o pseudônimo "Lésbia" indicava. A ideia de que apenas os homens escreviam "boa literatura" ou de que as mulheres năo eram bem-vindas nesse campo é o que marca o destaque da narradora, a dúvida do responsável pelo jornal expóe suas expectativas - e de toda uma sociedade - em relaçăo a quem está por trás de um texto literário bem formulado.

Pouco tempo depois, a escritora encontra o redator em bom momento, e ele lhe dirige palavras positivas, mostrando ser um homem sem preconceitos e "amigo do progresso" (BORMANN, 1998, p. 85). Como forma de manter relaçóes com a escritora, pede a ela que escreva folhetins semanais, estes que ela, primeiramente, recusa-se a escrever, mas ele insiste e recebe sua aceitaçăo. Ao voltar para casa naquele dia, Bela pensa que "já era muito tarde para refletir ou retroceder; seguiria o seu destino" (BORMANN, 1998, p. 86). Outro marcante momento da relaçấo de Bela com esse redator é que os colegas de redaçâo desconfiam de seus encontros com o chefe, o que a deixa indignada e a narradora nos conta que esse foi apenas o início dos dissabores que ela viveria como mulher no mundo das letras: "náo só o espírito brasileiro ainda se acha muito eivado de preconceitos, como também a maioria dos homens nâo vê com bons olhos essa emancipaçâo da mulher pelo estudo e pela independência de opiniōes" (BORMANN, 1998, p. 87). Por esses motivos, a relaçăo entre escritora e chefe era vista com olhos desconfiados pelos outros frequentadores do jornal.

Foi por pouco tempo que Bela escreveu no jornal, pois a folha desaparece com a ascensăo do Partido Liberal. Vale recordar que, no efervescente desenvolvimento da imprensa no Brasil oitocentista, muito comum era a abertura e o fechamento de jornais, muitos até mesmo publicavam uma única vez. Lésbia - a partir desse momento, a narradora já se refere à protagonista por esse nome - continua a compor seus versos e romances, estudando com ardor e aguardando um momento apropriado para

"Avante! avante!" em traduçấo literal. 
imprimi-los em livros, o que demandava muita reflexăo e economia, visto que era caro imprimir no Brasil de entăo.

Assim, chegamos ao capítulo XI, o mais interessante para análise da vida da escritora mulher no mercado editorial oitocentista. Como observamos, imprimir era caro naquele momento histórico e, por isso, a protagonista procura um editor que publicasse os seus romances e poemas, cedendo ela todos os direitos autorais. Acerca dessa questăo, Neves e Ferreira (2010) registram que, no Brasil independente, após 1822, a questáo dos direitos autorais se tornou um ponto permanente de discussáo ao longo de todo o século. Foi somente no final do Oitocentos que tais direitos foram finalmente consagrados. Elas escrevem:

A Constituiçấo de 1824 garantia o direito de propriedade em toda a sua plenitude, ao afirmar que os "inventores" tinham a propriedade de suas descobertas ou de suas produçóes. [...] No entanto, além de tal lei năo ser implementada, a Carta Magna năo inclui de forma explícita a questăo a propriedade intelectual. Embora fosse possível fazer uma analogia entre inventor e autor, em funçáo da natureza intelectual do trabalho e de seu caráter de originalidade, năo era assim que pensavam os homens da época. (NEVES; FERREIRA, 2010, p. 505).

Assim, por năo estar explícita a questâo da propriedade intelectual, os autores ficavam desemparados perante a lei. Por isso, enquanto a norma náo era regulamentada, continuou-se com as práticas vigentes durante o período colonial: solicitar ao soberano o privilégio de usufruir, por certo tempo, a exclusividade de determinada obra. Nessa época, essa concessăo era vista pela sociedade como "gestăo de mercê" e năo como um direito e, assim, as obras permaneciam no "domínio da graça". (NEVES; FERREIRA, 2010). Por esse motivo, sabemos que, na prática, dificilmente o escritor do fim do século conseguia viver do que escrevia, além de, muitas vezes, em vez de receber pagamento em dinheiro pelo seu trabalho, recebia apenas uma determinada quantidade dos livros impressos.

Nossa heroína tinha dois inconvenientes que a impediam de publicar: ser mulher e ser brasileira. Se até na França havia quem fosse contra a mulher como escritora, entre nós o preconceito era ainda maior. A narradora exemplifica com o caso de George Sand, que enfrentou muitos problemas para conseguir publicar na Europa, mas provou "quanto pode o gênio em um cérebro feminino" (BORMANN, 1998, p. 97-98). A França, vale ressaltar, era o maior modelo de civilidade para o Brasil, conforme Hallewell (2017, p. 156), "mesmo os costumes sociais extremamente conservadores do país [Brasil] estavam sendo lentamente transformados pela admissăo generalizada de que a França era a única naçâo civilizada no mundo ocidental". Portanto, ao dizer "contra a mulher de letras até na França era comum o preconceito" (BORMANN, 1998, p. 97), Délia reafirma essa visăo do país europeu.

A narrativa prossegue dizendo que "entre nós o preconceito e o atraso relegam a mulher, colocam-na sempre em segundo plano, aceitando ela paciente esse papel secundário por falta de cultura, ou por flexibilidade de ânimo, ou por efeito de educaçấo, ou para năo ocorrer em singularidade" (BORMANN, 1998, p. 98). Essas questôes referem-se à falta de educaçấo, a qual caminhou em "marcha lenta" para as alunas, como notamos no tópico sobre os papéis femininos. Ademais, a mulher "que tenta fugir à essa praxe; tem contra si, primeiramente as próprias mulheres movidas pela inveja, pelo 
ciúme ou por qualquer mesquinharia; depois, todos os homens, mordidos pelo despeito e indignados com a infraçáo desse soi-disant direito de supremacia, criado para seu exclusivo uso" (Idem). Além disso, a narradora questiona o fato de ser ela brasileira e, por causa disso, que atençâo poderia merecer "a que ousa transpor e quebrar o círculo de ferro que a todas encerra?" (Idem). Esse estrangeirismo, segundo a narradora, leva o brasileiro a sempre enaltecer outros países e matar o estímulo dos bons artistas nacionais. Apesar desses problemas, a corajosa Lésbia se entrega ao mundo das letras, em busca de seu reconhecimento.

Por ser muito laboriosa e paciente, mesmo as coisas ruins que aconteciam a ela, em vez de desanimar, serviam de força e incentivo. Quando foi procurar saber da decisăo do editor acerca da publicaçăo dos seus livros, viu que ele estava com evasivas, o que a revoltou. Mas esse homem de letras tinha uma indicaçăo de outro redator da Folha $\mathrm{X}$, o qual havia mostrado desejo de falar-lhe sobre seus escritos. Coincidentemente, esse redator, "homem modesto, de olhar límpido e sereno" (BORMANN, 1998, p. 99), chega ao espaço nesse momento e é apresentado à Lésbia: "sorriam as grandes almas em simpática atraçăo" (BORMANN, 1998, p. 100). O redator afirma que, por ser brasileira, este é o primeiro título de estima, demonstrando seu entusiasmo com os artistas locais. Tecendo elogios à escritora, ele avisa que ela enfrentará dissabores, devendo suportá-los, pois "na terra da banana, [...] literariamente, deve cada um tratar de si, lutando pela vida, disputando o seu quinhăo a dente e a unha e isentando-se do mínimo escrúpulo de camaradagem, como miseráveis deserdados sem proteçâo e sem guarida" (Idem). Ele a encoraja e, por fim, diz que seu jornal está de portas abertas para publicar as obras da autora, a qual fica emocionada com as falas do literato, respondendo que trabalhará com afinco e sempre lembrando dos determinantes avisos feitos por ele.

Ao informá-lo de que tem interesse em publicar seus romances, ele dá a resposta positiva de que os publicará em folhetins e, depois, fará uma ediçăo de mil volumes, sendo quinhentos para ela. Essa prática do folhetim era comum no mercado editorial da época, e destaca-se que a reediçâo desses folhetins sob a forma de livro era uma estratégia óbvia para o comércio livreiro, entretanto, no Brasil, a prática foi adotada de uma forma mais gradual e a proporçâo de folhetins que foram publicados em livros foi muito pequena. (HALLEWELL, 2017). Por fim, desse encontro, Lésbia sai com a alma alegre, palpitando pela ideia da glória literária.

Um mês após esse importante encontro, publica-se no rodapé da Folha X o romance Blandina, "maravilhoso tecido, bordado de peripécias, onde cada personagem era perfeitamente descrito em seus defeitos e qualidades, mostrando no estudo psicológico verdadeira mestria" (BORMANN, 1998, p. 103). A imprensa recebeu o romance com frieza e os literatos fingiram que náo o viram. Já a narradora observa que a obra era possuidora de um espírito másculo, mas com apurado trato feminil, sendo esse espírito "másculo" exemplo do que era "boa literatura" para os críticos, isto é, a literatura com traços ditos masculinos. Dentre os literatos citados, apenas um escreveu palavras de animaçăo, exprobrando a indiferença e induzindo-a a prosseguir.

Convém lembrar que, durante o século XIX, os poetas e ficcionistas brasileiros, ao lado dos críticos e teorizadores, revelaram-se como representantes de uma época em que se procurou legitimar a validade de uma literatura realmente brasileira. Dotados do poder da pena, os críticos liam as obras publicadas e teciam seus comentários. Acerca dessa atividade, entendemos que, quando uma obra merecia os olhos do intelectual e, 
como resultado, recebia frases elogiosas nos jornais, ela estava trilhando o caminho da canonizaçăo. De acordo com Lajolo e Zilberman (2019, p. 100-101): "Ser 'estudada com atençấo' constitui a primeira etapa da canonizaçăo de um escritor, de vez que a simples atençâo da crítica [...] já vale como reconhecimento da literariedade do texto, pré-requisito fundamental para a legitimaçăo de sua qualidade".

Isto é, se uma obra fosse lida a fundo por um estudioso, a fim de tecer comentários ou escrever tese sobre esse trabalho, isso seria prova suficiente de que tal conjunto de textos certamente possui os traços de literariedade que fazem dele "boa literatura". A crítica, neste caso, legitima a qualidade, como escreveram as autoras. Perguntamonos, como funcionava para os escritores que năo tinham laços com os críticos ou nâo fossem tidos como bem-vindos nos meios intelectuais de elite, como, por exemplo, as escritoras que, por conta do gênero, por muito tempo foram invisibilizadas na produçăo literária. No romance de Bormann, temos uma resposta a essa pergunta, visto que acompanhamos os problemas vividos por Lésbia nos ambientes literários.

Apesar dessa dificuldade enfrentada em relaçâo à recepçâo crítica, Lésbia cita o artista de teatro Talma, que dizia que "quando vejo na platéia (sic) um ou dois espectadores no caso de compreender-me, fico satisfeito e considero o teatro cheio" (BORMANN, 1998, p. 104-105). Assim também pensava a escritora, demonstrando que, se apenas um ou dois leitores atingissem o entendimento de seu trabalho, ela se daria por satisfeita em sua arte literária.

Acerca do público leitor feminino, a narrativa faz seus comentários: "em geral, incapazes de enunciar qualquer observaçáo sobre literatura, investiam as mulheres contra a moralidade de alguns personagens do romance, os quais, no entanto, poderiam servir-lhes de modelo em tudo e por tudo" (BORMANN, 1998, p. 105). Sobre isso, voltamos a relembrar que as mulheres da época tinham acesso limitado à educaçấo e, por isso, nâo poderiam enunciar observaçôes literárias. Dessa maneira, passaram a vociferar contra a autora, mas a narradora năo deixa de registrar que essas puristas com certeza faziam leituras proibidas a elas, como os chamados "livros para homens", os quais, de acordo com El Far (2010), sâo narrativas de teor pornográfico proibidas às mulheres, consideradas, naquele momento, pessoas de intelectos frágeis e, por isso, suscetíveis aos enredos amorosos. Esses romances tornaram-se grandes sucessos de tiragens e os leitores acompanhavam fielmente seus lançamentos nos jornais.

Também falavam mal do romance os maridos hipócritas, e as mulheres solteiras eram leitoras garantidas, procurando no romance traços da autora na personagem. 0 público em geral achou o trabalho de Lésbia imoral e diziam que ela era mais realista do que Emilé Zola, sobre isso a narradora comenta que esses "parvos" năo sabiam distinguir entre as escolas literárias, visto que Lésbia adotara o ecletismo, utilizando-se do que lhe era bem-vindo em diferentes escolas. Consola-se a autora de Blandina lembrando que também Balzac foi taxado de imoral, mesmo vivendo na culta França, que negou a ele tudo em vida, mas depois o reconheceu. Vale ressaltar o destaque dado novamente à nobreza da França.

Com toda essa dificuldade em relaçâo à sua recepçâo, perguntamo-nos por que ela năo desistiu e lemos no romance nossa resposta: "seguira o impulso do talento, que a alçava da terra, tornando-a indiferente às vulgaridades da vida, fazendo-a desprezar as torpes intrigas e os vis mexericos, em que se compraz a maioria das 
mulheres" (BORMANN, 1998, p. 108). Sobre a tiragem de Blandina, a narrativa nos conta que houve pouca extraçăo, provando que năo era imoral de fato, pois, se o fosse, os quinhentos exemplares teriam sido vendidos rapidamente. Ademais, os parentes da autora desejavam adquirir o livro, mas "esqueceram a rua e o nome do livreiro, onde poderiam comprá-lo" (BORMANN, 1998, p. 109). Nisto, a narradora cita que outro nacional sofreu do mesmo problema: todos queriam admirar o trabalho, mas náo queriam comprar. Esse outro autor era Gonçalves de Magalhăes que, quando teve seu Suspiros Poéticos Saudades financiado pelo mecenato do imperador, também náo encontrava os compradores esperados.

Meses depois, Lésbia publica um poema baseado em um romance de Alexandre Dumas, o qual os literatos apreciaram e teceram crítica positiva, o que pode ser explicado pela escolha do gênero, uma vez que, conforme Zahidé Muzart (1995), uma das razôes para a năo canonizaçâo das escritoras do século XIX é o gênero literário escolhido por elas. Para ela, na aceitaçăo da mulher escritora, essa questâo năo foi nada desprezível. "Verifica-se que as poetisas săo, em geral, aceitas, mesmo que o sejam apenas com benevolência, e que algumas foram respeitadas" (MUZART, 1995, p. 90-91). Ela exemplifica com o caso de Narcisa Amália, a qual foi citada e criticada em sua época e ainda o é atualmente pelos historiadores da literatura, mesmo que incluída entre os menores. A estudiosa conclui que, "dos gêneros escolhidos pelas mulheres, sâo as teatrólogas e as romancistas as mais esquecidas" (MUZART, 1995, p. 91), e explica que isso é facilmente entendido quando lembramos da temática nobre utilizada na poesia, flores e sentimentos maternais, sempre no âmbito da família. Por outro lado, a produçăo de outros gêneros năo seria padronizada desta forma.

Portanto, voltando à narrativa, percebemos que escrever poemas era um poderoso mecanismo para ser aceita pelos críticos na época. Depois, ela publica novo romance, seu favorito como autora, também considerado imoral, pois ela estava "marcada" desde Blandina, o que nos prova que o valor negativo de uma crítica valia por tempo indeterminado. Em vista de se vingar desses "zangôes literários" (BORMANN, 1998, p. 111), Lésbia escreve um poemeto satírico chamado "Os garotos", no gênero de Bocage, vendendo mil folhetos em menos de quinze dias, induzindo-a a cultivar esse produto de grande extraçăo.

Afastada de boa parte da sua família, a protagonista conhece o Dr. Pereira, a quem batiza como Catulo e com quem vive como amante. No capítulo XV, temos um acontecimento de grande magnitude para sua trajetória de vida: ela ganha na loteria. A partir disso, compra um belo palacete no Rio Comprido, onde vai morar na companhia dos pais. Lá, ela cria um gabinete de estudos e escrita valoroso e, nesse santuário, apenas Catulo pôde penetrar. A literata conversa com o amante sobre a diferença e semelhança entre a mulher e a escritora:

uma é a escritora, outra a mulher: em mim essas duas entidades estăo quase sempre em oposiçấo. De ordinário, obrigo os meus personagens a aceitar situaçôes penosas, às quais eu náo me sujeitaria de modo algum, o que náo me impede entretanto de sentir com eles, palpitando ao contrapeso dos choques que recebem: aí está o segredo da arte. (BORMANN, 1998, p. 129).

Ainda acerca de suas personagens, ela afirma que até as que se opóem à sua personalidade sâo parecidas com ela: "todos eles, mais ou menos, participam da minha 
natureza e vivem um pouco da minha existência, acontecendo muitas vezes compartilharem igualmente a minha índole dois caracteres opostos" (BORMANN, 1998, p. 141). Para Lésbia, há uma mistura de real e do fictício nas criaçôes dos poetas, os dissabores reais săo transformados, com o passar do tempo, em literatura: "Tornou-se a composiçăo parte essencial da minha existência; é um ato que, por assim dizer, a continua e completa" (BORMANN, 1998, p. 142).

A vida da escritora passa a ser dedicada completamente ao seu desenvolvimento literário, visto que náo precisava mais se preocupar com questōes financeiras depois que ganhou o prêmio na loteria. Sobre isso, recordamos o que Virginia Woolf apontou em Um teto todo seu (1929) sobre a mulher precisar de um espaço seu, o qual representa, para além de uma casa própria, a sua independência financeira, tăo difícil para uma mulher nos séculos anteriores. Em relaçăo ao romance de Bormann, o palacete é o "teto todo seu" necessário à dedicaçâo da mulher às letras, pois, sem essa independência, năo existiriam outros caminhos senáo ser máe e esposa: os modelos esperados das mulheres. Sem depender de outras atividades, ela pôde frequentar a sociedade só em ocasiôes necessárias a ela, como quando visava conhecer pessoas com intençáo de estudar tipos para suas ficçôes.

No capítulo XX, a narradora nos deixa saber que Lésbia, apesar dos dissabores, atingiu o seu objetivo literário, conseguindo entusiasmar até mesmo os compatriotas, os quais eram os mais difíceis de serem conquistados. Nesse momento de felicidade, tragédias se dăo em sua vida. Perdendo os pais, ela passa a abraçar o amor de Catulo ainda mais, com quem faz uma viagem há muito tempo querida para a Europa e, principalmente, Roma, "onde o gênio tem sua verdadeira sagraçăo" (BORMANN, 1998, p. 161). Voltando após oito anos para o Brasil, "recebeu uma estrepitosa manifestaçáo dos seus entusiastas em festejo ao feliz regresso à pátria de filha tăo ínclita" (BORMANN, 1998, p. 163).

Nesse regresso, Lésbia acaba conhecendo seu novo e último amor: um mancebo chamado Alberto, que tinha idade para ser seu filho e, por isso, a escritora năo vive esse amor como desejava. Ainda que os dois se apaixonem de forma recíproca, o destino nâo os permite viver essa paixăo, sendo esse o último sofrimento de Lésbia. Quando ela se pergunta como resolver esse problema, questiona a si mesma se deve ir embora do país, mas sua resposta é năo, pois lutou muito para ter seu reconhecimento aqui, como verificamos em nossa leitura. Uma última mençáo aos aborrecimentos com os literatos e com os críticos está no momento em que ela dá uma festa de aniversário, seguindo o conselho de Catulo, convidando a imprensa, os literatos e diversas famílias célebres, lembrando ela que, para isso, muitos terâo que fazer uma trégua com o ser que chamavam "imoral" a fim de esvaziar a adega desta, observaçăo ácida da protagonista sobre a hipocrisia social.

O desenrolar de seu último relacionamento é finalizado pela decisăo de Lésbia pelo suicídio, forma que encontrou para solucionar as tristezas que vinha vivendo. No dia determinado por ela, entra no gabinete e recorda que foi onde criou tantas obras que a haviam levado à glória tăo almejada, sonho enfim realizado e que, no entanto, deixava-a indiferente naquele momento, pois eram tăo grandes os seus sofrimentos. Ao escrever uma carta para o chefe de polícia, explica que aquele ato era "apenas mais uma excentricidade de mulher de letras, raça inútil e perniciosa, segundo a opiniâo 
de alguns cérebros resistentes e incapazes de vertigem" (BORMANN, 1998, p. 242). Assina como Arabela Gonzaga (Lésbia), e esta é a primeira vez em que o sobrenome dela é citado, bem como é notável destacar que ela registra nome e pseudônimo, pois os dois eram sua essência.

Poética é a cena da morte, escolhendo o método de Sêneca ${ }^{6}$ para morrer. Lésbia corta as veias das pregas dos braços com um bisturi e enxerga, em seu devaneio mortal, as personagens criadas por ela em vida recebendo-a na eternidade: "à imortalidade pertencia Lésbia!" (BORMANN, 1998, p. 249). Em seu velório, a narradora conta que discursaram aquelas mesmas vozes que um dia haviam tentado negar seus merecimentos, prova da falsa devoçăo dos mesmos literatos. Na porta do seu gabinete, Catulo observa a inscriçăo "Non omnis moriar"7 e seu testamento pede a ele que crie um asilo de educaçăo para órfăs desvalidas e um liceu para mulheres, mostrando como ela se importava com as bandeiras de luta femininas pela educaçâo. Além disso, ele fez imprimir de maneira luxuosa as obras inéditas da autora e escreveu a sua biografia, a qual terminou com as palavras de Byron: "Sê imortal, tu foste - tu mesma!" (BORMANN, 1998, p. 256).

\section{CONSIDERAÇÕES FINAIS}

Além da metamorfose de Arabela em Lésbia, isto é, da mulher que se torna escritora, o romance de Bormann aborda outras questóes, principalmente sobre o campo sentimental e erótico da protagonista, na vivência de diversos amores. Entretanto, nosso escopo de análise neste trabalho foi, como salientado, sua vivência nas letras. Com elementos que se misturam à vida real da autora, por ser ela também uma escritora brasileira no Oitocentos, a obra se tornou uma das mais importantes de sua carreira. Ainda que atualmente esteja sendo relida e estudada por alguns acadêmicos, os livros de Bormann continuam sendo de difícil acesso, pois apenas alguns deles foram reeditados pela Editora Mulheres, de Santa Catarina. Ademais, após o encerramento das atividades dessa editora, tornou-se ainda mais difícil o acesso ao conjunto da obra de Délia. Por considerarmos de grande prestígio o conteúdo e a forma como Délia escreveu, acreditamos que pesquisar e publicar sobre ela seja uma maneira de reavivar sua memória literária.

Em exercício de resgate, estudamos, por meio de trabalhos sobre a posiçăo social da mulher no Brasil oitocentista, o papel das mulheres nas letras brasileiras, o surgimento de nossa imprensa e compreendemos, assim, um pouco mais de que forma alguns detalhes expostos na narrativa de Bormann săo bastante realistas e podem ser rastros de como o mercado editorial funcionava para as mulheres escritoras que tentaram publicar naquela época. As dificuldades eram multiplicadas por questôes de classe, gênero e raça, sendo Délia uma mulher branca, de elite, com parentes ligados às letras, que pôde, assim, estudar, escrever e trazer a lume muitas de suas obras durante sua breve carreira, publicando até bem próximo de sua morte, aos 41 anos.

6 Lúcio Aneu Sêneca foi um dos mais célebres advogados, escritores e intelectuais do Império Romano. No ano 65, foi acusado de ter participado da conspiraçăo de Pisấo, na qual o assassinato de Nero teria sido planejado. Sem qualquer julgamento, foi obrigado a cometer o suicídio. É mais uma figura que reafirma a predileçâo de Délia pela cultura romana.

7

"Năo morrerei inteiramente", traduçâo do Latim. 
Apesar de notável carreira, o seu nome também foi se apagando dos principais compêndios literários e, por isso, justificamos esta pesquisa e revisitaçăo, pois, assim como Ignez Sabino em Mulheres Illustres do Brazil, queremos ressuscitar essas mulheres de exímio talento pertencentes a nossa história. Ao lermos e escrevermos sobre Délia, estamos reavivando sua imagem, memória e literatura, para que possamos năo deixar no passado os nomes de escritoras que contribuíram para a consolidaçăo da literatura brasileira no século XIX. Como afirma Sabino (1996, p. 198): "se năo se obscurecer o merecimento da mulher escriptora, o nome da Délia, tem direito a ser lembrado". 


\section{REFERÊNCIAS}

BARBOSA, Rui. Reforma do ensino primário e várias instituiçōes complementares da instruçăo pública. In: Educaçâo e Saúde, 1946.

Obras Completas. vol. X, tomo II. Rio de Janeiro: Ministério da

BLAKE, Augusto Victorino Alves Sacramento. Diccionario Bibliographico Brazileiro. Rio de Janeiro: Imprensa Nacional, 1900.

BORMANN, Maria Benedita Câmara. Lésbia. Florianópolis: Ed. Mulheres, 1998.

D'INCAO, Maria Ângela. Mulher e família burguesa. In: DEL PRIORE, Mary (org.). História das mulheres no Brasil. Sâo Paulo: Contexto, 2018, pp. 223-240.

DUARTE, Constância Lima. Imprensa feminina e feminista no Brasil: Século XIX: dicionário ilustrado. Belo Horizonte: Autêntica Editora, 2017.

EL FAR, Alessandra. Ao gosto do povo: as ediçōes baratíssimas de finais do século XIX. In: BRAGANÇA, Aníbal; ABREU, Márcia (orgs.). Impresso no Brasil: Dois séculos de livros brasileiros. Săo Paulo: Editora Unesp, 2010, pp. 89-99.

FONSECA, Cláudia. Ser mulher, măe e pobre. In: DEL PRIORE, Mary (org.). História das mulheres no Brasil. Sáo Paulo: Contexto, 2018, pp. 510-553.

HAHNER, June. Mulheres da elite. In: PINSKY, Carla Bassanezi; PEDRO, Joana Maria (orgs.). Nova História das mulheres no Brasil. Sáo Paulo: Contexto, 2018, pp. 43-64.

HALLEWELL, Laurence. O Livro no Brasil: Sua História. Trad. Maria da Penha Villalobos; Lólio Lourenço de Oliveira; Geraldo Gerson de Souza. 3 ed. Sáo Paulo: Editora da Universidade de Sáo Paulo, 2017.

LOURO, Guacira Lopes. Mulheres na sala de aula. In: DEL PRIORE, Mary (org.). História das mulheres no Brasil. Săo Paulo: Contexto, 2018, pp. 443-481.

MUZART, Zahidé Lupinacci. A questăo do cânone. Anuário de Literatura, Florianópolis, n. 3, pp. 85-94, 1995.

MUZART, Zahidé Lupinacci. Uma espiada na imprensa das mulheres no século XIX. Revista Estudos Feministas, Florianópolis, v. 11, n.1, pp. 225-233, jan./jun. 2003.

NEVES, Lúcia Maria Bastos P.; FERREIRA, Tania Maria Bessone da Cruz. Privilégios ou direitos? A questâo autoral entre intelectuais e homens de Estado no Brasil do século XIX. In: BRAGANÇA, Aníbal; ABREU, Márcia (orgs.). Impresso no Brasil: Dois séculos de livros brasileiros. Sáo Paulo: Editora Unesp, 2010, pp. 503-517.

SABINO, Ignez. Mulheres Illustres do Brazil. Ediçăo fac-similar. Florianópolis: Ed. Mulheres, 1996.

SANTOS, Salete Rosa Pezzi dos. Duas mulheres de letras: representaçôes da condiçâoo feminina. Caxias do Sul, RS: Educs, 2010.

SCHWARZ, Roberto. Ao vencedor as batatas: forma literária e processo social nos inícios do romance brasileiro. 5 ed. Săo Paulo: Duas Cidades; Ed. 34, 2000. 
TELLES, Norma. Introduçăo. In: BORMANN, Maria Benedita Câmara. Lésbia. Florianópolis: Ed. Mulheres, 1998, pp. 5-22.

VERONA, Elisa Maria. Da feminilidade oitocentista. Săo Paulo: Editora Unesp, 2013.

WOOLF, Virginia. Um teto todo seu. Trad. Bia Nunes de Sousa e Glauco Matoso. Săo Paulo: Tordesilhas, 2014. 